\title{
The Regulation of Clinical Trials in the Republic of Serbia
}

\author{
Zorica M. Vučinić ${ }^{1}$, Ljiljana C. Djukićc,3 \\ ${ }^{1}$ Medicines and Medical Devices Agency of Serbia, Belgrade, Serbia \\ ${ }^{2}$ Medicines and Medical Devices Agency of Serbia - retired, Belgrade, Serbia \\ ${ }^{3}$ Section for Clinical Pharmacology Serbian Medical Society, Belgrade, Serbia
}

\section{SUMMARY}

Introduction: Modern trends in drug production and traffic of drugs as a primary marketing resource of high quality efficient and safe drugs have an important task to provide safe, effective and quality medicines through clinical trials.

Topic: Overview of current regulations established in the field of clinical trials of drugs and the importance of carrying out clinical trials is pointed herein.

Methods: Pursuant to the applicable regulations in the Republic of Serbia and those established at the level of the European Agency (EMA) is provided an overview of the key elements essential for the objective procedures carried out in clinical trials of drugs in Serbia.

Conclusion: Modern drug therapy today is exposed to serious challenges given the numerous studies in the field of medicine and pharmacy carried out in the world today. Clinical trials are particularly vulnerable segment in this area and require the participants in these processes to be highly educated and to have the serious ethical approach to all stages of the process.

Keywords: clinical trials, regulation, EU directive, ALIMS

\section{INTRODUCTION}

Clinical trial - any investigation in human subjects intended to discover or verify the clinical, pharmacological and/or other pharmacodynamic effects of one or more investigational medicinal product(s), and/or to identify any adverse reactions to one or more investigational medicinal product(s) and/or to study absorption, distribution, metabolism and excretion of one or more investigational medicinal product(s) with the object of ascertaining its (their) safety and/or efficacy his includes clinical trials carried out in either one site or multiple sites, whether in one or more than one Member State.

\section{METHODS}

Pursuant to the applicable regulations in the Republic of Serbia and regulations established at the level of the European Agency (EMA) is provided an overview of the key elements essential for the objective procedures carried out 
in clinical drug trials in Serbia.

\section{TOPIC}

Regulations applied within clinical trials [1] in Serbia are in line with European regulations more precisely with the Main EU Directive- EU DIRECTIVE 2001/20 / EC OF THE EUROPEAN PARLIAMENT AND OF THE COUNCIL of 4 April 2001 and THE COMMISSION DIRECTIVE 2005/28/EC of 8 April 2005

Clinical trials in Republic of Serbia are laid down by following regulations:

- The Law on Medicines and Medical Devices ("Official Gazette of RS "Nr. 30/2010 and 107/12).

- Regulations on the contents of the request and documentation for the approval of clinical trials of medicinal products and medical devices and conducting clinical trials of medicinal products and devices ("Official Gazette of RS”,Nr.64/211 and 91/2013),including ICH /E11 guidelines on Clinical testing of drugs on children.

- Regulations on the methods of reporting, collecting and monitoring adverse drug reactions ( "Official Gazette of RS ",Nr.64/211).

- DKP Guidelines, ICH-E6 ("Official Gazette of RS", Nr.28/2008).

- Annex 13-Production of clinically tested drug ("Official Gazette of RS", Nr.28/2008).

These regulations are determined by the conditions under which clinical trials in Serbia are conducted, the responsibilities of sponsors, ethical committees, researchers, control of clinical trials and other issues in the field of clinical trials. In Republic of Serbia, clinical trials are conducted in accordance with the highest European and international standards or guidelines for good clinical practice representing ethical and scientific quality standard in conducting clinical trials. Documentation submitted in the procedure for approving clinical trials is consistent with the documentation required in EU countries. Agency for Medicines and Medical devices (ALIMS) is authorized for tasks related to clinical trials in our country, primarily for the issuance of licenses for clinical trials of medicinal products and medical devices, for issuing a permit to import the drug or medical device clinically tested, monitoring pharmacovigilance in clinical trials and to control implementation of all processes. In average, 90 clinical trials for drugs and medical devices are approved per year in Republic of Serbia. In Serbia, all phases of clinical trials are conducted, but in terms of the number of studies by phases phase III trials are most frequent.

License for the conduct of clinical trials shell be issued within 60 days from the day the application is evaluated to be complete. Sponsors who are not based in the Republic of Serbia can have a legal entity as a representative, or an agent based in the Republic of Serbia, who is responsible for documentation and obtaining authorization for clinical trials and pharmacovigilance in clinical trial conducts.

The ALIMS shall implement and supervise the conduct of clinical trials to determine whether the approved clinical trials are carried out in accordance with the protocol established by national regulations and guidelines of good clinical practice and in order to protect the health and safety of subjects.

In ALIMS clinical trials of drugs are in the Medical sector which performs the issuance of licenses for clinical trials and control clinical trials, when the Sector for permits authorizing the import of a drug that is in clinical trials.

Clinical trial - any investigation in human subjects intended to discover or verify the clinical, pharmacological and/or other pharmacodynamic effects of one or more investigational medicinal product(s), and/or to identify any adverse reactions to one or more investigational medicinal product(s) and/or to study absorption, distribution, metabolism and excretion of one or more investigational medicinal product(s) with the object of ascertaining its (their) safety and/or efficacy his includes clinical trials carried out in either one site or multiple sites, whether in one or more than one Member State;

Subject is a person participating in the CT of drug confirms its subject's informed consent on written statement, containing both the date and the signature, on participation in a certain clinical trial, provided by an entity capable of giving consent or, if incapable of giving consent, by its legal representative, in accordance to the Law, given voluntarily after being thoroughly informed about the nature, significance, consequences and health risks.

The law also defines that the clinical trial of drugs (CT), studies performed on humans to determine the clinical, pharmacological or pharmacodynamic effects of one 
or more of the study drugs, or to identify any adverse reactions, to one or more study drugs examine the absorption, distribution, metabolism and excretion in order to determine their safety and efficacy.

A clinical trial may be conducted if:

- The benefits of the tested drug is greater than its potential risk to the life and health of patients (previously conducted preclinical trials)

- The Ethics Committee of the legal entity, in which the clinical trial is been conducted, ruled that the therapeutic benefit of the medicinal product under the trial, and its importance for the protection of life and health of subject, justify its potential risks.

- Subjects, or their legal representatives, are completely informed, in writing and language they can understand, about the clinical trial, and of their right to withdraw their consent to participate in a clinical trial at any time.

- Subjects right to the psychological and physical integrity, privacy and protection of personal data in the procedure of clinical trials are ensured.

Clinical trials must not be carried out on:

1. healthy persons who have not attained the age of 18 ;

2. healthy pregnant women and nursing mothers;

3. persons accommodated in social care institutions;

4. persons who are placed in health care facilities or institutions for penitentiaries by court decision;

5. persons whose coerced or otherwise induced into giving consent to participate in clinical trials, and to give free consent for participating in clinical trials.

If necessary, and under special precautionary measures, clinical trials can be performed on persons under the age of 18 , pregnant and breastfeeding women, suffering from a disease or condition for which are medical product been clinically investigated, is intended to.

Sponsor in the process of obtaining licence for the implementation of CT, sponsor shall submit to the Agency the fallowing documentation.

A new drug, or a drug already registered, which will be tested in a different way than the approved Summary of Product Characteristics (SPC) to a new indication for a second population, in the new pharmaceutical form.
The documentation for the approval of clinical trials of medicines shall contain:

1. Covering letter by the sponsor;

2. Protocol;

3. Protocol Synopsis in the Serbian language;

4. Information on adverse reactions to the medicine, unless part of the Investigator's Brochure;

5. Investigator's Brochure;

6. Investigational Medicinal Product Dossier (IMPD), i.e. the documentation from the investigational medicinal product dossier in another format if the sponsor does not have the required documentation prepared in the IMPD format;

7. Summary of Product Characteristics with authorization;

8. Case Report Form (CRF);

9. Decision of the ethics committee of the healthcare institution that will implement the clinical trials, and/or ethics committees if they are multicentre clinical trials;

10. Written consent by the general manager of the healthcare institution, and/or healthcare institutions wherein the clinical trials of the medicine will take place;

11. Documentation on the investigational medicine, Good Manufacturer Practice certificate of a European Union country or another country with the same or similar requirements regarding Good Manufacturer Practices, and/ or a certificate on the application of Good Manufacturer Practice issued by the competent ministry pursuant to the law, and/or a report by the inspection for medicines of the competent ministry on compliance with the conditions for the manufacture of medicines for clinical trials, no older than six months, an analysis certificate, labelling for the medicine in the Serbian language and the original language, both for the medicine being tested, as well as the comparative medicine;

12. Certificate confirming that the material of animal or human origin being used in the production of the medicine does not pose a risk of transmission of spongiform encephalopathy TSE certificate, if required;

13. Additional requirements for medicines with specific characteristics (genetically modified organisms, radiopharmaceuticals);

14. Certificate of Good Manufacturing Practice for the location of the production of the active biological substance of a European Union country or another country with the same requirements regarding Good Manufacturer Practice, and/or a statement by a person 
qualified for releasing a series of medicines for clinical trials confirming the active biological substance was manufactured pursuant to Good Manufacturing Practices for active substances, and/or a report by the inspection of the competent ministry on the compliance of the manufacturing of the active biological substance with the Guidelines of Good Manufacturing Practice for active substances no older than six months,

15. Written statement by the principal investigator of being familiar with the properties of medicines in clinical trials and the goal of the clinical trials, as well as on conducting the trials pursuant to the regulations in effect and the principles of Good Clinical Practice;

16. Evidence of the importer of the medicine for clinical trials holding an authorization for the wholesale of medicines issued by the competent ministry;

17. Brief resume and references for the principal investigator;

18. Evidence of the sponsor insuring persons undergoing clinical trials in case of health damage to subjects for the period of the implementation of clinical trials;

19. Form for subject information and written consent signed by the subjects, in the Serbian language;

20. Validated copy of the contract on the transfer of authorization to the contract research organization;

21. Other subject information (patient journal, instructions, etc. in the Serbian language);

22. List of countries where the medicine obtained authorization;

23. List of countries where clinical trials for the same medicine were approved, and/or approvals of ethics committees and authorized bodies;

24. List of places where the same clinical trials of medicines are being conducted, if the trials are multicentre trials;

25. Additional information related to the protection of subject health, at the request of the Agency;

26. Evidence of having paid the prescribed tariffs to the Agency for issuing authorizations for the clinical trials of the medicine.

The agency assesses the content of the request for $\mathrm{CT}$, documentation and render a decision within approximately 60 days from the day the documentation is evaluated to be complete.

The Agency in this process shall issue approval for substantial amendment within 30 days. Amendment may essentially relate to: the protocol implementation CT, study drug, preclinical pharmacological and toxicological data and clinical data.

Sponsor is obliged to inform the Agency and the EC on the completion of CT ,within 90 days. In case of early completion of $\mathrm{CT}$, this period shall be reduced to 15 days and the reason for completion must be clearly explained.

\section{Good Clinical Practice}

Good Clinical Practice (GCP) in clinical trials of drugs is an international ethical and scientific quality standard for designing, implementing, recording and reporting the tests conducted on humans. Compliance with these standards ensures public confidence in the rights, safety and welfare of subjects protected in accordance with the principles of Helsinki Declaration and that data from clinical trials is authentic.

Good Clinical Practice guidelines regulate the liability of participants in a clinical trial as:

- Ethics Committee

- Sponsor

- Principal Investigator

Guidelines define the basic documentation, consisting of documents that individually or collectively permit evaluation of the conduct of clinical trials and the quality of data obtained throughout clinical trial. These documents shell demonstrate that the investigator, sponsor and monitor respected Good Clinical Practice and applicable regulations.

Continuous monitoring of the conduct of clinical trials by the sponsor through monitoring and audit by the competent authority through control / inspection ensures quality of implementation of the clinical trials, primarily in relation to the monitoring of safety, respect for the rights and welfare of subjects.

Beside industrial initiated commercial clinical trials, academic investigator initiated studies are the very important area of interest for applied science progress in Europe and Planet too.

\section{CONCLUSION}

The process of approval and conduct of clinical trials in Serbia complies with the regulations 
that apply in the EU, in particular, as regards compliance with the highest international ethical and scientific standards - Guidelines for Good Clinical Practice, and in order to enable patients in Serbia with the latest modern diagnostics and therapy in the treatment of.

The Agency for Medicines and Medical Devices of Serbia (ALIMS), on the basis of well-established professional documentation base on drugs in a relatively short time of its existence, invested their professional capacity and with the support of eminent experts develop this activity and improves procedures according to the latest regulations to scientific and professional achievements.

\section{REFERENCES}

1. Serbian Legislation for Clinical Clinical Trials available at http://www.alims.gov.rs/ciril/regulativa/

2. Law on medicinal products and medical devices. "Official Gazette of the Republic of Serbia" No. 30/2010 dated 7th May 2010.

3. Rulebook on the Contents of the Application, and/or Documentation on the Approval of Clinical Trials for Medicines and Medical Devices, as well as the Method of Implementation for Clinical Trials of Medicines and Medical Devices The Rulebook hereof was published in the "Official Gazette of the RS", nr. $64 / 2011$ of 31 August 2011

4. Rulebook on the method of reporting, collecting and monitoring adverse reactions to medicines . "Official Gazette of RS", No. 64/2011 of 31 August 2011

5. NOTE FOR GUIDANCE ON CLINICAL INVESTIGATION OF MEDICINAL PRODUCTS IN THE PAEDIATRIC POPULATION (CPMP/ICH/2711/99)

6. ICH Topic E 6 (R1) Guideline for Good Clinical Practice. European Medicines Agency. CPMP/ ICH/135/95, July, 2002.GUIDANCE ON GOOD CLINICAL PRACTICE (CPMP/ICH/135/95)

7. EU Anex-13, Volume 4 EU Guidelines to Good Manufacturing Practice for Investigational Medicinal Products for Human Use.

8. DIRECTIVE 2001/20/EC OF THE EUROPEAN PARLIAMENT AND OF THE COUNCIL of 4 April 2001

9. COMMISSION DIRECTIVE $2005 / 28 /$ EC of 8 April 2005. Official Journal of the European Union L91/13-L91/19.

10. Marković SZ, Kastratović DA, Kubiak C, Demotes Mainard J. ECRIN - Needed in European Science. Hospital Pharmacology. 2015; 2(2):279-282. www. hophonline.org

11. Žagar ZA. Clinical Trial Insurance in Serbia. Hos- pital Pharmacology - International Multidisciplinary Journal. 2015; 2(1):189-198. www.hophonline.org

12. Mugoša SS, Stanković MV, Turković NM, Bešović ŽM, Šahman-Zaimović MM, Drljević MD. Pharmacovigilance: Empowering Healthcare Professionals. Hospital Pharmacology. 2015; 2(2): 255-260. 


\title{
Regulativa kliničkih ispitivanja u Republici Srbiji
}

\author{
Zorica M. Vučinić ${ }^{1}$, Ljiljana C. Djukićc ${ }^{2,3}$ \\ ${ }^{1}$ Agencija za lekove i medicinska sredstva Srbije, Beograd, Srbija \\ ${ }^{2}$ Agencija za lekove i medicinska sredstva Srbije - autor sada u penziji, Beograd, Srbija \\ ${ }^{3}$ Sekcija za Kliničku farmakologiju Srpskog lekarskog društva, Beograd, Srbija
}

\section{KRATAK SADRŽAJ}

Uvod: Savremena kretanja u farmaciji, proizvodnji i prometu lekova kao primarni resurs stavljanja u promet kvalitetnih, efikasnih i bezbednih lekova imaju značajan zadatak da kroz klinička ispitivanja lekova obezbede bezbedne, efikasne i kvalitetne lekove.

Tema: $U$ radu se daje pregled uspostavljene aktuelne regulative u oblasti kliničkih ispitivanja lekova i ukazuje na značaj sprovođenja kliničkih ispitivanja.

Metodologija: Na osnovu važećih propisa u Republici Srbiji i onih koji su uspostavljeni na nivou Evropske agencije (EMA) daje se prikaz ključnih elemenata koji su bitni za objektivne procedure koje se sprovode u kliničkim ispitivanjima lekova u Srbiji.

Zaključak: Savremena farmakoterapija danas je izložena ozbiljnim izazovima obzirom na brojna istraživanja u oblasti medicine i farmacije koja se sprovode danas u svetu. Klinička ispitivanja su posebno osetljiv segment u ovoj oblasti koji zahteva od učesnika u tim procesima visoku edukovanost kao i ozbiljan etički pristup svim fazama ovih procesa.

Ključne reči: klinička ispitivanja, EU direktive, regulativa, ALIMS 